\title{
ПОЛІФУНКЦІОНАЛЬНІСТЬ ХУДОЖНЬОЇ ДЕТАЛІ В ПОВІСТІ Т. ОСЬМАЧКИ «СТАРШИЙ БОЯРИН»
}

\begin{abstract}
У статті досліджується поліфункиіональність художньої деталі в повісті Т. Осьмачки «Старший боярин», виявляється оригінальний багатий спектр художніх деталей у мития. Виділяється три основні типи - одиничні, наскрізні й система деталей. Серед одиничних деталей, які в основному виконують роль часопросторових локусів у повісті, виокремлюються майстерні пейзажні деталі. У видатного прозаїка пейзажна художня деталь вступає у ширші смислові зв'язки з іншими мікрообразами й образами твору. До наскрізних відноситься низка психологічних деталей, серед яких особливими є видіння, сни, марення, містичні голоси й співи. Систему художніх деталей презентують градачійні ряди звукових, зорових деталей.

Наголошується на тому, щуо автор свідомо в центрі композиції творить сільський пейзаж, щуо створює відповідну художню умовність. У селі реальне поєднане з ірреальним, події одночасно відбуваються в різних часових i просторових вимірах, минуле переплелося із сучасним. Автор ідеалізує патріархальне село засобом яскравих художніх деталей. 3 'ясовується специифіка художньої деталі, щчо виконує естетичну функцію художнього хроHomony.

У статті виявлено й проаналізовано складні взаємозв'язки між деталями як одного, так і різних типів - одиничних з одиничними, наскрізних з наскрізними, одиничних з наскрізними і т. д. Акцентується увага на тому, щчо в індивідуальному стилі письменника система деталей-це такий взаємозв'язок деталей, щэо веде до появи нових семантичних значень або художніх смислів.

Зазначається, щуо творчість видатного прозаїка засвідчила подальшу еволючію художньої деталі, розширення ї̈ ідейно-смислових можливостей. Резюмується, щзо, по-перше, в аналізованій повісті змінюються прийоми створення яскравої образної одиничної та наскрізної деталей. По-друге, ускладнюється проиес взаємодії між окремими типами деталей, між деталями різних типів, все ширше письменник вдається до складної розгалуженої системи деталей. По-третє, підвищуються зображально-виражальні якості деталі, насичення ї̈ ідейнохудожнім змістом.
\end{abstract}

Ключові слова: художня деталь, хронотоп, топос, локус, мікрообраз.

Tetiana BANDURA, orcid.org/0000-0001-9999-0523 Candidate of Philological Sciences, Associate Professor at the Department of Ukrainian and Foreign Literature South Ukrainian National Pedagogical University named after K. D. Ushynsky (Odesa, Ukraine) tatyanabandura03@gmail.com

\section{POLYFUNCTIONALITY OF ARTISTIC DETAIL IN T. OSMACHKA'S STORY "SENIOR BOYAR"}

The article examines the multifunctionality of artistic detail in the story of T. Osmachka "Senior Boyar". It turns out the original rich range of artistic details of the artist. There are three main types - single, through and system of parts. Among the single details that mainly play the role of space-time loci in the story "Senior Boyar», masterful landscape details stand out. In the case of an outstanding prose writer, a landscape artistic detail enters into broader semantic connections with other microimages and images of a work. A number of psychological details belong to the pervasive ones, among which visions, dreams, delusions, mystical voices and songs are special. The system of artistic details is presented by gradation series of sound and visual details.

It is emphasized that the rural topos and, obviously, the landscape, are deliberately placed by the author in the center of the composition and create a corresponding artistic convention. In the village, the real is combined with the unreal, events occur simultaneously in different temporal and spatial dimensions, the past is intertwined with the present. The author idealizes the patriarchal village by means of bright artistic details. The specifics of an artistic detail that performs the aesthetic function of an artistic chronotope are clarified. 
The article identifies and analyzes the complex relationships between details of one and different types of artistic details - single with single, through with through, single with through, etc. Emphasis is placed on the fact that in the individual style of the writer system of details - it is such a relationship of details of one or different types that leads to the emergence of new semantic meanings or artistic meanings.

It is noted that the work of the outstanding prose writer testified to the further evolution of the artistic detail, the expansion of its ideological and semantic possibilities. It is summarized that, first, in the analyzed story the methods of creating a bright figurative single and through details change. Secondly, the process of interaction between separate types of details, between details of different types becomes more complicated, the writer increasingly resorts to a complex branched system of details.

Key words: artistic detail, chronotope, topos, locus, microimage.

Постановка проблеми. В історії кожної національної літератури $є$ художні твори, поява яких зумовила полеміки, дискусії, роздуми про важливість виховання духовності засобом літературного твору. Суперечливим було сприйняття чи несприйняття таких творів реципієнтом і критикою, проте безперечним $є$ визнання їхньої художньої цінності в контексті світової літератури через високу оригінальність письма, новаторську ілюстрацію стилістичних пошуків, поетикальної системи та демонстрацію самобутньої концепції міфомислення автора.

До таких мистецьких феноменів можемо віднести невелику прозову спадщину українського письменника Т. Осьмачки, визнаного літературною спільнотою після складного шляху становлення в умовах жорстоких репресій.

Аналіз досліджень. У сучасному літературознавстві проза митця нерідко ставала об'єктом наукового дослідження. Екзистенційну природу епічних творів письменника розглядали у своїх наукових працях В. Барчан, Н. Зборовська, Н. Колесниченко-Братунь, О. Лапко, Н. Михайловська, О. Надточій, О. Піскун, М. Скорський, О. Слоньовська, І. Смолій, Г. Токмань та ін. У міфологічному аспекті з урахуванням численних алюзій і ремінісценцій з Т. Шевченка та М. Гоголя творчість Т. Осьмачки досліджували Ю. Мариненко, О. Мірошник, І. Стребкова та ін. Певним поетикальним елементам прози автора, зокрема специфіці художньої деталі, уваги приділялося менше, особливо у визначенні функціональності.

Мета статті - дослідження функціональності художньої деталі в повісті Т. Осьмачки «Старший боярин».

Виклад основного матеріалу. Спектр художніх деталей у митця надзвичайно багатий, проте серед них можна виділити три основних типи одиничні, наскрізні й систему деталей. Серед одиничних деталей, які в основному виконують роль часопросторових локусів у повісті «Старший боярин», виділяємо майстерні пейзажні деталі. У видатного прозаїка пейзажна художня деталь вступає в ширші й, можна сказати, валентніші смислові зв'язки з іншими мікрообразами й образами твору.

Наведемо приклад пейзажної деталі з глибоким символічним наповненням, що продукується в антропоморфній структурі. Дія «Старшого боярина» відбувається в 1912 році в найблагодатнішу пору року - в першій половині літа, серед буяння розкішної природи, щедро напоєної сонцем. Сонце становить епіцентр пейзажних замальовок повісті, воно супроводжує героїв, бере участь у настрої, психічному стані, самовідчутті персонажів. Персоніфікований образ небесного світила виразно відображає міфологічне сприйняття Сонця як «...вищої сили, центру буття, яке призначив Всебог освітлювати й зігрівати землю і давати ій плодючість» (Войтович, 2002: 497). Таке сприйняття акумулює означення «життєдайне сонце», що неодноразово вживається в тексті. Сонце - джерело світла й тепла, під його лагідним промінням все оживає й радіє буттю, воно сповнює світ красою й спокоєм, наприклад, у такій картині червневого недільного ранку:

«Кожні груди живої істоти дихали безмежною глибиною супокою і потуги, яка непомітно викликалася сонцем 3 надр землі і переливалася в кожне стебло і в кожне живе серце. Дихали радісно, глибоко і з таким чуттям, яке говорило, що можна дихати ще радісніше, ще глибше і ще тихше...» (Осьмачка, 1998: 15).

Антропоморфне сприйняття сонця відбито й в оригінальному порівнянні його 3 господарем: «...Йому здався день незвичайно тихий і широкий своєю пусткою, але в якій сонце не могло потовпитися - бувши надміру великим, воно набирало величезних зусиль, аби розгорнутися на весь розмах своєї потуги. I, здавалося, воно почувало себе серед літнього дня так, як спітнілий, розпарений господар у маленькій коморі, увійшовши туди 3 поля дістати з бодні сала» (Осьмачка, 1998: 30).

Таким чином, автор уводить у «живу» систему персонажів персоніфікований образ сонця, надаючи йому смислотвірного значення в оповіді, наголошуючи на міфологічному підгрунті деталісимволу. 
Особливо виразно зв'язок зазначеного образу 3 давнім солярним культом українців виступає в останньому, чотирнадцятому розділі повісті, де в картині сходу сонця небесне світило порівнюється з нареченою, яка напередодні весілля обходить село, запрошуючи родичів на своє свято:

«...Вранішні пташині звуки він сприймав наполовину як співи дружок тієї молодої, що ходить по селу напередодні вінчання і запрошує родичів на весілля <..> А ті велетенські дві тополі, між якими були ворота в двір, світилися до розпеченого сходу блискучим ряботинням листків. 3 першого погляду думка говорила, що то висять на гілляках тисячі маленьких дзеркалець, і ворушаться вітром, і світяться сонцем $<\ldots>$ Де вона, заквітчана квітками від чола через голову аж до намист та до китиць, мішаних на спині широкими різнокольоровими стрічками. А! Ось голова ії підводиться над селом. А її прикраси, зачепившись за садки та за хати і за далекий ліс, натяглися до небес, неначе пасма гарячого проміння. Сонце. Сонце! Це сонце так зустрічають півні. Це вони співають, а не дружки» (Осьмачка, 1998: 93).

Сонце в образі нареченої пов'язане $з$ давніми народними уявленнями небесного світила як живої істоти, що грає. За цим віруванням, «у дні великих свят Сонце на сході переливається різними кольорами або підскакує, миготить, зупиняється і т. ін.» (Войтович, 1998: 498). Письменник розширює колірну систему ліричних образів, високохудожніх епітетів, яскравих промовистих метафор, залучаючи золотий, гарячий, блискучий, світлий відтінки кольорів художнього пейзажу. Народнопоетичні речові художні деталі наповнюють уривок різноголоссям природних явищ (дзеркальця, квітки, намиста, китиці, стрічки і т. д.). Про це грандіозне видиво в народі говорили «Сонце до вінця йде» (Войтович, 2002: 499). Елементи весільного дійства відображають і тексти українських колядок та щедрівок, де сонце уособлює жінку, господиню, а місяць - чоловіка, господаря, причому «фольклорний мотив шлюбу небесних світил має прадавнє, ще індоєвропейське коріння» (Войтович, 2002: 499).

Дихотомічною складовою частиною «небесної пари» у творі виступає місяць, символіка якого «пов'язана $з$ лунарними міфами, де він завжди знаходиться в опозиції до Сонця» (Москаленко, 1998: 82). Справді, найбільш фантастичні дійства твору відбуваються саме вночі, за повного панування місяця з його магічним світлом. Події, які розгорнулися в уяві Гордія, а потім і в дійсності, теж відбувалися в межовий, міфічний час - о дванадцятій годині ночі. Це не випадково, адже місяць - «символ циклічного ритму часу, духовного аспекту світла в пітьмі» (Москаленко, 1998: 82), йому підвладний космос. У пейзажній картині повісті місяць виконує функцію господаря нічного світу. Тому коли від тужливої пісні Марфи нап'ялися небеса, «і посеред ночі від наглого місяця стало світліше і моторошніше <..>, він, ніби це відчувши, став важко і повільно осідати над церквою. I знизився на найвищий гостряк хреста. Хрест не витримав, тріснув і 3 місяцем упав в ограду...» (Осьмачка, 1998: 20).

Сакральна художня деталь - хрест у видінні Гордія не випадкова. Міфологічна символіка хреста пов'язується з Деревом Життя, «світовою віссю, союзом духовного принципу і принципу світу явищ; стражданнями, муками, боротьбою $<\ldots>$, агонізуючою біллю життя $<\ldots>$, спасінням через страждання...» (Москаленко, 1998: 135). Сюжетотвірна функція містично-сакральної художньої деталі полягає в репрезентації авторської ідеї - трансляція через жіночу пісню всієї глибини страждань понівеченої української душі, розп'яття самої України, що втілилася в священному образі співаючої жінки-душі.

Міфологічного змісту набувають і пейзажні художні деталі в експозиційній картині опису села, до якого підходить головний герой Гордій Лундик. Він потрапляє до обійстя Горпини Корецької, яке символізує родинне гніздо, морально-етичні основи роду, його стійкості. Гордій повинен перейти річку - символ розподілу світів, щоб потрапити в зовсім інший світ - руйнації й боротьби. Для посилення сюжетної інтриги митець в описі навколишнього пейзажу виділяє окремі промовисті пейзажні деталі, які з огляду на народний світогляд мають містичне значення: яр - глибока, безлюдна, дика місцина; зарослий дерезою рів, «місцевість навколо спуску через стрімучу крутість ніколи і ніким не оброблялася» (Войтович, 2002: 120); болотяна рослинність - рогоза, очерет, що вже створює уяву про щось нечисте, надприродне; дерева, що своєю символічною семантикою підкреслюють відповідне функціональне навантаження: верби, тополі, осики, явори. Основним локусом дії $\epsilon$ річка, де, за міфологічними традиціями, зазвичай відбувалися обрядоворитуальні дійства. Саме від річки, за порадою ворожки, почала Варка своє відьомське чаклування, щоб заспокоїти душу матері, котра «встає 3 того світу і йде у <...> берег і співає вночі» (Осьмачка, 1998: 40).

Прикметною в повісті «Старший боярин» $\epsilon$ градаційна система художніх звукових деталей, що створюють у тексті різнорідну картину природних звуків-шумів. Для прикладу наведемо декілька звучних уривків: 
«Луна від людських розмов і крику пастушків, від мекання овець та іржання коней, реву волів та корів йшла в поле зо всіх царин села мальовничим звучанням, як і село, пройняте туманом, було кольористе на ранкові фарби» (Осьмачка, 1998: 15). Автор вводить у художнє полотно поряд зі звуковими деталями й зорові через колірну палітру ранкової картини.

«...Видно було, як красувалися жита і стояли густі зелені пшениці, над якими звисали кібці й звеніли жайворонки. А ім знизу здавленою луною відповідали перепелиці хававканням. Дикі качки та лиски з польових озер криком. І лисиці, скликаючи лисенят гаркітливим лящанням. А бджоли, оси i джмелі тягли через поля свою окрему, гостру і тужливу прекрасну мелодію...» (Осьмачка, 1998: 18).

Нагромадження звукових і зорових художніх деталей у пейзажних картинах створюють ідилічну картину «святої землі». «В архаїчному, релігійному досвіді та міфологічній інтуїції Земля $є$ місцем (пунктом у просторі), в якому людина віднаходила себе. Як показують етнологічні дослідження, <..> те, що називаємо «святістю землі», в дійсності є «святістю місця» (у розумінні локалізації відносно космосу). Це означає, що кожна людина має свої корені в землі, вона зв'язана з певним місцем. Ним найчастіше буває місце народження, рідний край» (Москаленко, 1998: 176). Саме таким сакральним місцем виступає в Осьмаччиній повісті українське село. Автор свідомо ставить у центрі композиції сільський топос, що створює відповідну художню умовність. У селі реальне поєднане 3 ірреальним, події одночасно відбуваються в різних часових і просторових вимірах, минуле переплелося iз сучасним. Засобом яскравих художніх деталей митець ідеалізує патріархальне село з полями, що буяють хлібами, охайними садибами, садками, криницями, церквою, з тужливою піснею під місяцем, 3 купальськими святами. Навіть повсякденні життєві реалії не знижуються в митця до побутового рівня, їх теж охоплює струмінь ідеалізації: «...сонця вже було повен двір. I кукурікання, і квокання, і кудакання, і пищання курчат здавалося криком соняшного світла» (Осьмачка, 1998: 25). Описуючи домашнє господарство Горпини Корецької 3 урочистістю й піднесеністю, письменник переводить епічну оповідь в площину ліричної через паралельне зображення абсолютно побутових земних і недосяжних небесних процесів.

Акордним у цій системі градаційних звуків $\epsilon$ звучання тієї тужливої пісні - глибокої психологічної деталі, що згодом набуває ознак наскрізної: «I саме в цю мить щось у яру заспівало таким сумним, чистим та високим голосом, що луна від нього нестримною потугою покотилася через село повз церкву в степ і вдарилася в високе небо - і воно над степом і селом і над осяяним від місяця церковним хрестом не видержало тієї туги, що підіймали людські звуки у немирінність ночі $<\ldots>$ не видержало і стало возноситись вище і вище $<\ldots>>$ стало розходитись ширше і ширше... (Осьмачка, 1998: 11). Локального звучання набувають вже згадані символічні художні деталі хреста й місяця.

Пейзажі в «Старшому боярині» - то частка, елемент образу України, і в них не завжди спостерігаємо спокійне естетське замилування красою природи. «Автор «Старшого боярина» <... був апологетом старосвітської, сільської України», - стверджує дослідник Ю. Мариненко (Мариненко, 2016: 155). Природа в письменника одухотворена такою мірою, ніби наслідує кожний порух людини. Слугують цьому вдало підібрані, інколи несподівані, художні деталі. За технікою виконання малюнки природи в повісті близькі до імпресіоністичних пейзажів, але 3 оригінальним вкрапленням деталей побуту. Т. Осьмачка $з$ головою поринає в лірико-романтичну стихію, оперуючи в ній і яскравими епітетами, і несподіваними метафорами, і образами-символами.

Таким чином, у трьох уривках повісті спостерігаємо різні кольори, різну тональність і різну настроєвість. Але у всіх - яскраво виражена динаміка барв і звуків, майстерне володіння засобами персоніфікації. Кожен із цих літературних малюнків має й певне ідейно-смислове навантаження. Літературознавець М. Скорський вказує на визначальні риси стильової манери Осьмачки-прозаїка: «У стилевій манері «Старшого боярина» відразу відчувається Осьмачкапоет $з$ його ліризмом оповіді, образною символікою, пісенними мотивами, казковими видіннями та пригодами» (Скорський, 2000: 144).

Так, приміром, спокійний світлий пейзаж літнього дощового ранку підсилює романтичну мрію письменника про майбутнє України, де пануватиме гармонія природи й людського буття. Осмислюючи художню сутність «Старшого боярина», дослідники сходяться на думці, що центральним у повісті став саме узагальнений, синтетичний образ України. В нього, як пише Ю. Шерех, «влилися і природа, і національні характери, і загальний колорит, і якісь незримі аморфні частини фольклорного стилю й світосприймання, і пристрасть самого автора» (Шерех, 1999: 178).

Не менш промовистою в тексті «Старшого боярина» була портретна деталь. Ї̈і Т. Осьмачка вимальовує ще 3 більшою художньою ретель- 
ністю. Портрети у автора не розлогі, а лаконічні й дещо містико-таємничі. Вже перша зустріч Гордія з Варкою демонструє авторський варіант знайомства молодих людей в умовах таємниці ночі: «Побачив перед собою, кроків на двадцять, жіночу постать, і то, лише в одній білій сорочці. Вона йшла, кваплячись, стежкою на гору i не оглядалася. На спині чорніла розпущена пишная коса. Йому прийшло в голову, що видиво похоже на казку, в якій відьми і потопельниці конче 3 розпущеним волоссям» (Осьмачка, 1998: 13). Портретна деталь «розпущена коса» апелює до відьомської зовнішності. Як правило, міфологія й світова класика подає образ відьми як вродливої звабливої жінки, яка небезпечна своїм коханнямзгубою. Зустріч молодих людей увінчалась цілком побутовою речовою деталлю - дівочою хусткою, що залишилась у руках парубка. Хустка - символ власне фемінної суті, річ, що навіки пов'яже дві самобутні долі, зв'яже серця дівчини й хлопця у великому почутті кохання.

В ідилічну картину українського села вривається образ Маркури, виписаний в дусі народної демонології з використанням прийому гіперболізації, розлогої метафорики. Це демон, «якого не було від утворення світу і не буде до страшного суда», «напасть на весь хрещений мир», - говорить Горпина Корецька (Осьмачка, 1998: 24). Дослідниця І. Стребкова справедливо наголошує на жанрових ознаках казки в повісті, акцентуючи увагу на осередку «казкового» зла - образі Маркури: «Історія про зведення зі світу жінок Маркурою Пупанем стає вузловою темою, через яку послідовно пояснюються наслідки тих трагічних подій» (Стребкова, 2015: 110).

Бувальщина про Маркуру в устах оповідачки перетворюється на міф про страшну істоту. «Коли він їхав, чути було, як стогне земля. Здавалося, що їде військо незриме <..> I землі було трудно, і вона стогнала...» (Осьмачка, 1998: 85). Витворений авторською уявою Пупань повністю відповідає семантиці слова «демон». Він наділений чаклунським впливом на людей, володіє непоборною силою, зваблює жінок. Він носій зла і смерті. Виразною портретною деталлю є очі злого потвори: «Він такий велетень, та такі страшні в нього очі, та такі стидкі та тягучі, що я почула, прости Господи, хіть до нього непереборну» (Осьмачка, 1998: 22). Очі демона символізують магічну силу, якій підвладне все живе, водночас автор вказує на містичну дію цих очей полонити жінок своєю маскулінною суттю. Через глибинну суть демона - очі - автор увиразнює думку про аморальну субстанцію ворожої влади.

Ознаки демонічної сили закладені і в семантиці кольорів: домінуючим у його оточенні є чорний колір і символи на означення пекла: Пупань мав чорного коня, копита в якого «світилися як розпечені казани», а Горпина відчувала від Маркури «пекельний вогонь» (Осьмачка, 1998: 25). Нищівну, руйнівну суть несе вогонь - символічна художня деталь. Разом із Маркурою гине одинадцять сміливих тернавських чоловіків. А голос зганьбленої, збезчещеної Марфи, яка співає свою сумну пісню, з того часу лунає 3 яру, віщуючи лихо.

Висновки. Отже, в повісті Т. Осьмачка «Старший боярин» спостерігаємо складні взаємозв'язки між деталями як одного, так і різних типів - одиничних $з$ одиничними, наскрізних $з$ наскрізними, одиничних з наскрізними і т. д. В індивідуальному стилі письменника система деталей - це такий взаємозв'язок, що веде до появи нових семантичних значень або художніх смислів.

Творчість видатного прозаїка засвідчила подальшу еволюцію художньої деталі, розширення iii ідейно-смислових можливостей. По-перше, в аналізованій повісті змінюються прийоми створення яскравої образної одиничної й наскрізної деталей. По-друге, ускладнюється процес взаємодії між окремими типами деталей, між деталями одного типу, все ширше письменник вдається до складної розгалуженої системи деталей. По-третє, підвищуються зображально-виражальні якості деталі, насичення іiі ідейно-художнім змістом.

\section{СПИСОК ВИКОРИСТАНИХ ДЖЕРЕЛ}

1. Войтович В. Українська міфологія. Київ : Либідь, 2002. 662 с.

2. Мариненко Ю. Селянський рай Тодося Осьмачки (повість «Старший боярин»). Науковий вісник Миколаївського державного університету імені В. О. Сухомлинського : збірник наукових праць. Миколаїв : МНУ ім. В. О. Сухомлинського, 2016. С. 153-159.

3. Москаленко М. Фольклорний алфавіт давньоруського космосу. Київ : Український письменник, 1998. 274 с.

4. Осьмачка Т. Старший боярин. План до двору. Київ : Український письменник, 1998. 239 с.

5. Скорський М. Тодось Осьмачка. Життя і творчість. Київ : Український центр духовної культури, 2000.224 с.

6. Стребкова I. «Старший боярин» Тодося Осьмачки як казка. Література та культура Полісся : Серія «Філологічні науки» : збірник наукових праць. Ніжин : НДУ імені М. Гоголя. 2015. Вип. 74. С. 107-125.

7. Шерех Ю. Стилі сучасної української літератури на еміграції. Пороги і запоріжжя. Література. Мистеитво. Ідеологї. Харків : Фоліо, 1999. Т. 1. С. 161-195. 


\section{REFERENCES}

1. Voitovych V. Ukrainska mifolohiia. [Ukrainian mythology]. Kyiv : Lybid, 2002. 662 s. [in Ukranian].

2. Marynenko Yu. Selianskyi rai Todosia Osmachky (povist «Starshyi boiaryn»). [Peasant Paradise of Todos Osmachka (the story «Senior Boyar»)]. Naukovyi visnyk Mykolaivskoho derzhavnoho universytetu imeni V. O. Sukhomlynskoho : zbirnyk naukovykh prats. Mykolaiv : MNU im. V. O. Sukhomlynskoho, 2016. S. 153-159. [in Ukranian].

3. Moskalenko M. Folklornyi alfavit davnoruskoho kosmosu. [Folklore alphabet of ancient Russian space]. Kyiv : Ukrainskyi pysmennyk, 1998. 274 s. [in Ukranian].

4. Osmachka T. Starshyi boiaryn. Plan do dvoru. [Senior boyar. Plan to the yard]. Kyiv : Ukrainskyi pysmennyk, 1998. 239 s. [in Ukranian].

5. Skorskyi M. Todos Osmachka. Zhyttia i tvorchist. [Todos Osmachka. Life and work]. Kyiv : Ukrainskyi tsentr dukhovnoi kultury, 2000. 224 s. [in Ukranian].

6. Strebkova I. «Starshyi boiaryn» Todosia Osmachky yak kazka. [«Senior Boyar» by Todos Osmachka as a fairy tale]. Literatura ta kultura Polissia : zbirnyk naukovykh prats. Seriia «Filolohichni nauky». Nizhyn : NDU imeni M. Hoholia. Vyp. 74. 2015. S. 107-125. [in Ukranian].

7. Sherekh Yu. Styli suchasnoi ukrainskoi literatury na emihratsii. Porohy i zaporizhzhia. Literatura. Mystetstvo. Ideolohii. [Styles of modern Ukrainian literature in exile. Thresholds and zaporozhye. Literature. Art. Ideologies]. Kharkiv : Folio, 1999. T. 1. S. 161-195. [in Ukranian]. 